ISSN: 1641-4713; e-ISSN: 2081-1160

DOI: https://doi.org/10.36551/2081-1160.2020.26.83-110

\title{
Açorianidade e brasilidade nas Festas do Divino: o caso de Viana (ES)
}

\author{
Azorean and Brazilian Identity in the Feasts of the Divine Holy Spirit: \\ the case of Viana (ES)
}

\author{
Renata Siuda-Ambroziak \\ Universidade de Varsóvia, Polônia \\ Universidade do Estado do Rio de Janeiro (UERJ), Brasil \\ ID ORCID: https://orcid.org/0000-0002-6594-0058 \\ E-mail: r.siuda@uw.edu.pl \\ Fabiene Passamani Mariano \\ Instituto Federal do Espírito Santo (Ifes), Brasil \\ Universidade Federal do Espírito Santo (Ufes), Brasil \\ ID ORCID: https://orcid.org/0000-0002-3049-0536 \\ E-mail: fabiene.mariano@ifes.edu.br
}

Recepción: 3.03.2020

Aprobación: 10.04.2020

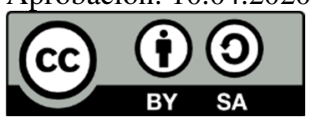

Resumo: Em 1813, foi fundada a Colônia Agrícola de Viana com a instalação de imigrantes portugueses das Ilhas dos Açores. As famílias açorianas, além de buscarem sucesso econômico e social, também trouxeram suas bagagens culturais. Entre elas se destacava a sua religiosidade e a Festa do Divino Espírito Santo, o objeto do nosso estudo, que ocorre em Viana desde o ano de 1817. Trata-se, portanto, de uma Festa bicentenária, carregada de simbolismos materiais e imateriais, que conserva em sua estrutura o script ritual semelhante ao que ainda ocorre nos Açores, entretanto, absorvendo e mantendo também características próprias da cultura local capixaba ebrasileira. Neste estudo, revisitamos o contexto histórico do surgimento e realização da Festa nos Açores, comentamos brevemente sobre a sua difusão no Brasil e analisamos a Festa em Viana, a partir de narrativas dos participantes.

Palavras-chave: festa religiosa, Festa do Divino Espírito Santo, Brasil. 


\begin{abstract}
In 1813, the Agricultural Colony of Viana was founded with the settlement of Portuguese immigrants from the Azores Islands. The Azorean families, in addition to seeking economic and social success, also brought their cultural background, including the object of our study: the Feast of the Divine Holy Spirit, which has been taking place in Viana since 1817. It is a bicentennial festival, full of material and immaterial symbolism, which preserves its structure, the ritual script similar to the one still occurring in the Azores, however, absorbing and maintaining also important characteristics of the local, capixaba and Brazilian culture. In this study, we revisit the historical context of the emergence of the Feast and the way it is held in the Azores. We comment briefly on its diffusion in Brazil and we analyze the Feast in Viana, basing on the narratives of its participants.
\end{abstract}

Keywords: religious feasts, Feast of the Divine Holy Spirit, Brazil.

\title{
INTRODUÇÃO
}

A festa é sempre um terreno privilegiado de expressão social e simbólica que se apresenta como testemunho da memória individual e coletiva e da dinâmica em que estão inseridos os indivíduos e seus vários grupos: sociais, culturais, étnicos... A celebração festiva está sempre inscrita em uma ampla rede de manifestações culturais, incluindo a fala, a gastronomia, a religiosidade, os saberes e fazeres. Segundo Guarinello (2001, p. 972) a festa é "uma produção do cotidiano, uma ação coletiva, que se dá num tempo e lugar definidos e especiais, implicando a concentração de afetos e emoções em torno de um objeto que é celebrado e comemorado e cujo produto principal é a simbolização da unidade dos participantes na esfera de uma determinada identidade". Para nós, neste estudo, se trata da concentração de afetividade dos habitantes de Viana-ES em torno da tradicional devoção ao Espírito Santo no contexto da identidade cultural açoriana (real, imaginada ou até desconhecida) e, ao mesmo tempo, capixaba e brasileira. Trata-se aqui de uma Festa tradicional açoriana, carregada de simbolismos materiais e imateriais, que conserva em sua estrutura o script ritual, semelhante ao que ainda ocorre nos Açores, entretanto, mantendo também características próprias da cultura local e evoluindo junto com todas as mudanças contemporâneas dela.

O século XIX foi uma época de grande movimentação emigratória nos Açores, de onde muitos vieram para o Novo Mundo. Em novembro de 1812, por intermédio da Intendência Geral de Polícia, o primeiro grupo de imigrantes açorianos chegou à Capitania do Espírito Santo. Alguns meses depois, em fevereiro de 1813, essas famílias foram assentadas na Colônia Agrícola de Viana, nas proximidades do Rio Santo Agostinho, onde ergueram suas moradas, cultivaram suas terras, estabeleceram seus costumes e exerceram sua religiosidade, o que podemos constatar através da construção da Igreja Matriz Nossa Senhora da Conceição, em 1815, e da Festa do Divino Espírito Santo, celebrada pela primeira vez em 1817 (Balestrero, 2012, p. 116). 
Ao refletirmos sobre a origem açoriana da Festa do Divino Espírito Santo na cidade de Viana e a complexidade dos processos que envolvem atualmente sua execução na cultura local, abordamos e analisamos os principais aspectos dessa celebração: o surgimento, as mudanças, as ressignificações e as permanências dessa expressão religiosa e cultural açoriana no contexto do repositório de memórias e sentidos originais atribuídos aos seus rituais, mesmo que esses tenham sido ignorados, esquecidos ou alternados com o passar do tempo e seu progressivo 'abrasileiramento'. Para tanto, utilizamos dados obtidos por meio da pesquisa bibliográfica, bem como da observação participante e das entrevistas semiestruturadas aplicadas através da metodologia de história oral.

\section{AS ORIGENS DA FESTA}

Os festejos decorrentes do culto do Espírito Santo são designados nos Açores como "Festas do Espírito Santo" ou "Impérios", e, tendo em vista sua ampla difusão, essa celebração é considerada "a mais importante festa de origem portuguesa fora de Portugal" (Leal, 2017, p. 11). As origens da Festa do Espírito Santo remontam os finais do século XIII e o início do século XIV em Portugal. A narrativa proposta com maior insistência e a mais disseminada é a "isabelina", que situa a origem da Festa durante o reinado de D. Dinis e da rainha Isabel de Aragão (beatificada em 1517 e canonizada em 1742), na cidade de Alenquer. A inspiração divina revelada à rainha Isabel através de um sonho, resultou na construção de uma igreja dedicada ao Espírito Santo e, em decorrência desse fato, algumas intervenções milagrosas. Outra variante apresenta como mito fundador a promessa feita pela rainha Isabel ao Espírito Santo, em favor do restabelecimento da paz entre o rei D. Dinis e o seu filho legítimo (e herdeiro do trono), o príncipe Afonso. Após alcançar a graça, ela mandou confeccionar uma réplica da coroa do reino para o cumprimento dessa promessa, assim como instituiu um dia dedicado ao culto do Espírito Santo: no dia de Pentecostes, em procissão solene, levou a coroa à igreja do Espírito Santo, iniciando uma grande celebração. A Festa contou com o cerimonial imperial - que incluía os cortejos e a coroação dos pobres, feita pela rainha com sua própria coroa, e, também, com a partilha de um grande banquete entre todos os convidados. A partir de então, essa Festa passou a ocorrer anualmente, respeitando sempre a mesma data em que ocorreu a primeira, ou seja, no dia de Pentecostes (Leal, 2017, p. 29). A Festa do Espírito Santo, depois da sua implementação em Portugal, apareceu também nos territórios colonizados pelos portugueses e, pelo advento da expansão marítima, chegou 
aos Açores. Foram os ilhéus açorianos os principais responsáveis pela disseminação desse culto nos países para os quais depois emigraram, incluindo o Brasil (Leal, 1994, pp. 15-16).

O arquipélago de Açores é marcado não somente por uma grande diversidade geográfica, mas também das práticas sociais, culturais e assim - religiosas dos habitantes (Leal, 1994). Com relação ao culto do Espírito Santo, apesar de toda essa diversidade, um núcleo de ocorrências se repete de forma regular nas Festas de toda a região.

O destaque da Festa é o papel de imperador, trazendo prestígio para a pessoa e para sua localidade. Os imperadores são sorteados ou selecionados com o auxílio da "comissão do Império", que se responsabiliza pela manutenção dos edifícios que compõem a parte estrutural da Festa e dos objetos relacionados ao culto, assim como pela nomeação dos mordomos - participantes que auxiliam os imperadores em algumas demandas, principalmente na angariação de recursos para a realização das festividades.

O preparo das atividades relacionadas ao seu dia de festejos corre principalmente aos imperadores. Para isso, podem contar com o auxílio de familiares e amigos, sob as mais diversas formas: dinheiro, trabalho, doações de animais e gêneros alimentícios. Sua responsabilidade direta com o custeio da Festa gira em torno de 30 a $60 \%$, sendo que o restante é angariado por meio de ofertas de moradores da localidade. A realização de um Império é encarada como uma "promessa pessoal" ou espécie de garantia do bem-estar coletivo com a proteção divina, especialmente relacionada a questões naturais, como a ocorrência de abalos sísmicos e crises vulcânicas ou, ainda, como uma espécie de garantia da prosperidade agrícola.

O período tradicionalmente consagrado para a realização das Festas do Espírito Santo nos Açores é conhecido como "tempo dos Impérios", entre o domingo de Páscoa e o domingo da Trindade. As Festas do Espírito Santo se tornaram grandes motivadoras para o deslocamento temporário de emigrados de volta para os Açores (Leal, 1994, p. 98) e as principais responsáveis pelo aumento do número dos chamados "Impérios fora do tempo". Isso ocorre devido à disponibilidade de deslocamento dos imigrantes estar vinculada ao período de férias, não coincidindo com o dia de Pentecostes.

As Festas do Espírito Santo contam com o apoio estrutural de um conjunto de edificações. Além da igreja e das residências dos imperadores e mordomos, existem estruturas arquitetônicas específicas, construídas com a finalidade quase exclusiva de servir aos festejos, a saber: os impérios (capelas para guardar 
as insígnias do Divino após o término dos festejos), os coretos (o palco) e as copeiras (estrutura para preparo e consumo das refeições). No conjunto arquitetônico que abarca os festejos nos Açores, a igreja e seu entorno recebem uma decoração especial. É no interior das igrejas que ocorrem as cerimônias de coroação com a coroa do Espírito Santo. Além da coroa, outro símbolo comumente utilizado é a "bandeira do Espírito Santo". Confeccionada em damasco de seda, na cor vermelha, geralmente é ornada com franjas douradas, os motivos da coroa e a pomba do Espírito Santo e com bordados em motivos florais na cor dourada.

Os rituais que integram uma Festa do Espírito Santo nos Açores estão divididos em duas categorias sequenciais: a "fase preliminar dos Impérios" e o "dia de Império", ponto culminante dos festejos, que ocorre na igreja e nos demais edifícios que integram a estrutura dos festejos. Em algumas ilhas, acontecem as "rezas do terço" durante toda a semana das festividades em homenagem ao Espírito Santo e cortejos com portadores das coroas, bandeiras e demais insígnias do Espírito Santo recebidos com uma "chuva" de pétalas de flores (Medina, 2007, p. 79).

$\mathrm{O}$ “dia de Império” inclui o cortejo de transferência do império, a coroação e os demais rituais que envolvem a distribuição de alimentos (Leal, 1994, p. 117). Durante as Festas do Espírito Santo, todos os mantimentos são consumidos de forma gratuita e por um grande quantitativo de pessoas, sejam elas vinculadas à organização, integrantes da comunidade ou apenas visitantes. Na ementa, o carrochefe é sempre a comida típica açoriana: a sopa do Espírito Santo ${ }^{1}$, o cozido açoriano $^{2}$, a alcatra ${ }^{3}$, a massa sovada ${ }^{4}$. Após o encerramento dos rituais religiosos e da distribuição das funções, é iniciado o "arraial", ou seja, um momento de socialização entre todos os participantes nas imediações do império (edifício) (Leal, 1994).

As "arrematações", que são uma espécie de leilão, cujo valor arrecadado é revertido em favor do Império, acontecem após a apresentação da filarmônica, em frente à porta do império. Geralmente, os itens disponíveis para a arrematação não variam muito conforme a localidade: vão desde pães de massa sovada, pedaços de carne assada, sopas do Espírito Santo, peças de alfenim e, até, animais vivos.

\footnotetext{
${ }^{1}$ A sopa do Espírito Santo é preparada com carne bovina temperada com canela e hortelã, servida com fatias de pão de trigo embebidas no caldo.

${ }^{2} \mathrm{O}$ cozido açoriano é um prato feito à base de carne de porco, frango, toucinho, chouriço, couve e alguns tipos de legumes.

${ }^{3}$ Nos Açores, a alcatra não significa apenas um corte bovino, e sim um modo especial de preparo da carne cozida em um tacho de barro, num caldo preparado com vinho e especiarias.

${ }^{4}$ A massa sovada é um tipo de pão, feito com farinha de trigo, ovos, açúcar, manteiga, banha e fermento.
} 
Para ilustrar o fenômeno da multiplicação das Festas do Espírito Santo é comumente utilizada a expressão "a cada canto seu Espírito Santo", ou seja, cada Festa é celebrada de acordo com as particularidades locais, mas preservando "o símbolo por excelência da identidade regional açoriana" (Leal, 2017, p. 37). Um dos primeiros destinos da difusão da Festa era o Brasil, com primeiros festejos organizados pelos açorianos em Santa Catarina e no Rio Grande do Sul, no final do século XVIII (Leal, 2017, p. 38). Nos séculos seguintes, outras localidades brasileiras também passaram a celebrar o Espírito Santo por influência dos açorianos. A diversidade tornou-se uma característica marcante das Festas expostas a processos "de transformação, de diferenciação, de hibridização" (Leal, 2017, p. 58), geradas pelo contato com outras culturas locais - a difusão das Festas do Espírito Santo se apresenta como o principal gatilho de sua transfiguração, permitindo o desuso de alguns elementos em substituição ao surgimento de outros, ocasionando uma renovação contínua nos sentidos e significados da Festa.

\section{As Festas do Divino No BRASIL}

A data preferencialmente utilizada para a realização das Festas do Divino no Brasil é o domingo de Pentecostes, mas a sua celebração pode ocorrer em outras datas, principalmente quando vinculadas a acontecimentos especiais e outras festas religiosas (Leal, 2017, p. 58).

De uma forma geral, a simbologia do Divino utilizada no Brasil é similar à que se utiliza nos Açores - a coroa, a pomba e a bandeira do Divino. Quanto aos papéis desempenhados na organização da Festa, no Brasil predomina o título de imperador, tendo sua nomenclatura por vezes substituída por "festeiro" ou "mordomo". Os rituais adotados nas Festas do Divino no Brasil podem variar muito, assim como a quantidade de eventos agregados à festa propriamente dita. Em algumas localidades, as cerimônias são mantidas num formato mais discreto e intimista; em outras, são realizados verdadeiros espetáculos, com ornamentos, trajes e cerimônias luxuosas, que podem ocasionar o dispêndio de significativo recurso financeiro.

O modo de circulação do alimento nas Festas realizadas no Brasil também se apresenta de forma bastante variada. Coexistem refeições abertas ao público com outras mais restritas, distribuições em recintos fechados ou ao ar livre, refeições gratuitas ou cobradas, enfim, múltiplas variações que ocorrem por conta das ressignificações da Festa quando exposta aos costumes locais. Os alimentos servidos durante os festejos geralmente estão relacionados à gastronomia local, mas em algumas localidades se relacionam à manutenção das tradições açorianas (Angelo, 2011, p. 280). 
Tabela - Comparativo entre as Festas de Mossâmedes, Mogi das CruZes e Gravataí

\begin{tabular}{|c|c|c|c|}
\hline \multicolumn{4}{|c|}{ TABELA COMPARATIVA DAS FESTAS DO DIVINO } \\
\hline Localidade & Mossâmedes - GO & Mogi das Cruzes - SP & Gravataí - RS \\
\hline Primeira Festa & 1790 & 1752 & 1859 \\
\hline Organização & Igreja, comunidade e poder público & Igreja e comunidade local & Igreja, comunidade e poder público \\
\hline Duração da Festa & 10 dias & 11 dias & 9 dias \\
\hline Época de realização & $\begin{array}{l}\text { inicialmente em agosto, atualmente } \\
\text { em maio }\end{array}$ & Semana de Pentecostes & Semana de Pentecostes \\
\hline Encargos & $\begin{array}{l}03 \text { Imperadores (escolhidos pelo padre) } \\
+ \text { Corte de ajudantes }\end{array}$ & $\begin{array}{l}01 \text { Imperador e } 01 \text { Imperatriz } \\
\text { (escolhidos pelo bispo) , casal Capitão } \\
\text { doMastro }\end{array}$ & $\begin{array}{l}\text { Imperador e Imperatriz (sorteados) } \\
\text { Alferes da Bandeira, Tamboreiro }\end{array}$ \\
\hline Simbologia & $\begin{array}{l}\text { Coroa, Cetro, Bandeiras da folia e } \\
\text { Bandeiras do Divino }\end{array}$ & $\begin{array}{l}\text { Bandeira do Divino (confeccionada sob } \\
\text { encomenda para cada imperador), } \\
\text { Pomba do Divino, Mastro, Coroa e } \\
\text { Cetro. }\end{array}$ & $\begin{array}{l}\text { Bandeiras do Divino, Mastro, Coroa e } \\
\text { Cetro. }\end{array}$ \\
\hline Rituais religiosos & Procissão, Folias, Novena e Missa & $\begin{array}{l}\text { Abertura do Império, Missas, } \\
\text { Procissões, Alvorada e Novena. }\end{array}$ & $\begin{array}{l}\text { Novenas, Procissões, Tríduo, Missas, } \\
\text { Coroação. }\end{array}$ \\
\hline Outros eventos & $\begin{array}{l}\text { Quermesse no domingo à noite com } \\
\text { barraquinas de comidas, leilão e } \\
\text { apresentações culturais }\end{array}$ & $\begin{array}{l}\text { Visitação do império e Quermesse } \\
\text { beneficente, Entrada dos Palmitos. }\end{array}$ & $\begin{array}{l}\text { Levantamento do mastro, Jantares, } \\
\text { Apresentações culturais, Almoço } \\
\text { festivo. }\end{array}$ \\
\hline $\begin{array}{l}\text { Distribuição gratuita } \\
\text { de Alimentos }\end{array}$ & $\begin{array}{l}\text { somente nas folias - alimentos doados } \\
\text { pelos donos das fazendas. }\end{array}$ & $\begin{array}{l}\text { Café da manhã após as rezas na igreja; } \\
\text { "Afogado" após o encerramento da } \\
\text { Entrada dos Palmitos; Lanche para os } \\
\text { participantes do cortejo do Mastro; } \\
\text { Rosa-sol mistura alcoólica bebida aos } \\
\text { pés do mastro. }\end{array}$ & Pão do Divino ao término da procissão \\
\hline Espaços da Festa & \begin{tabular}{|l|} 
Igreja, Praça em frente à igreja, \\
Fazendas do município, Rancho alegre e \\
Cinema (destinado à realização do \\
baile)
\end{tabular} & $\begin{array}{l}\text { Igreja, Império (capela construída } \\
\text { provisoriamente na praça da igreja), } \\
\text { sub impérios (casa do capitão do } \\
\text { mastro, escolas e universidades) } \\
\text { ginásio de esportes (para realização da } \\
\text { quermesse com barracas e atrações } \\
\text { culturais durante todos os dias da } \\
\text { festa). }\end{array}$ & $\begin{array}{l}\text { Igreja, salão Paroquial e praças do } \\
\text { entorno }\end{array}$ \\
\hline $\begin{array}{l}\text { Principais formas de } \\
\text { custeio }\end{array}$ & $\begin{array}{l}\text { Folias e doações espontâneas da } \\
\text { comunidade }\end{array}$ & $\begin{array}{l}\text { Antigamente: folias e recursos dos } \\
\text { imperadores. Atualmente: patrocínio } \\
\text { de grandes empresas }\end{array}$ & $\begin{array}{l}\text { Doações da comunidade, } \\
\text { comercialização de jantares e } \\
\text { patrocínios de empresas locais }\end{array}$ \\
\hline Contra-dádiva & não há informações & $\begin{array}{l}\text { Sim. O lucro da lojinha montada no } \\
\text { salão paroquial é destinado a } \\
\text { instituições beneficentes da } \\
\text { localidade. As barracas da quermesse } \\
\text { são exploradas por diversas instituições } \\
\text { do município. }\end{array}$ & $\begin{array}{l}\text { Não. O lucro dos festejos é aplicado na } \\
\text { manutenção da igreja. }\end{array}$ \\
\hline
\end{tabular}

Fonte: elaboração própria a partir de: Brandão, 1985; Cruz, 2014; Moraes, 2003.

Similar ao que ocorre com a circulação do alimento, a sequência ritual das Festas no Brasil também varia em seus modos de composição conforme os costumes locais. A realização geralmente depende dos imperadores (ou festeiros) e do apoio de sua rede de contatos - família, vizinhança e comunidade. No passado, as Festas do Divino eram geralmente protagonizadas por pessoas de classes sociais menos abastadas, sobretudo até o século XX. Como reconhecimento simbólico pela amplitude alcançada no Brasil, as Festas do Espírito Santo vêm atraindo o interesse das elites políticas e intelectuais do país. Esse fato pode ser comprovado a partir dos processos de registro da Festa como patrimônio imaterial, sejam eles em âmbito nacional, estadual e até mesmo municipal (Festas do Divino 
Espírito Santo de Pirenópolis - GO e de Paraty - RJ como patrimônio imaterial do Brasil, realizado pelo Instituto de Patrimônio Histórico e Artístico Nacional IPHAN; da Festa do Divino Espírito Santo da Irmandade do Divino Espírito Santo como patrimônio imaterial catarinense pelo Governo do estado de Santa Catarina; Festa do Divino de Piracicaba - SP, como patrimônio imaterial municipal).

Visando demostrar a variedade dos modos de festejar o Divino no Brasil, apresentaremos uma breve comparação entre três festas, realizadas em diferentes estados/regiões: a Festa de Mossâmedes, em Goiás; a Festa de Mogi das Cruzes, em São Paulo, e a Festa de Gravataí, no Rio Grande do Sul. As Festas em questão foram selecionadas por apresentarem pontos de interseção com a Festa de Viana, principalmente no que tange ao processo migratório que originou os festejos na localidade, ao poder exercido pela Igreja local na condução dos festejos e ao tempo de realização das festas - as três tiveram sua primeira edição há mais de duzentos anos.

\section{A FeSTA do Divino EsPírito SANTo EM Viana}

Considerando a celebração festiva como fruto de uma herança sociocultural e histórica, enfatizamos agora a Festa do Divino Espírito Santo na cidade de Viana - ES como uma herança dos imigrantes açorianos, que hoje constituem apenas uma pequena minoria da população. As práticas culturais açorianas foram, portanto, efetivamente disseminadas, compartilhadas com os demais habitantes e recriadas em Viana a partir do contato com as novas influências socioculturais no território brasileiro.

Visando oportunizar um detalhamento analítico da Festa do Divino em Viana, seus elementos foram agrupados em três diferentes eixos, conforme a categorização da memória proposta por Pollak (1989): os lugares da Festa, os atores da Festa e os acontecimentos da Festa. Ao todo, no processo de conhecer a Festa do Divino em Viana, foram entrevistadas 16 pessoas, classificadas em três categorias de perfis: os religiosos, os integrantes da equipe de organização da comunidade católica e os imperadores e imperatrizes de duas famílias com experiências na Festa do Divino em Viana, em diferentes épocas. 
TABELA: CATEGorias DE ENTREVISTADOS

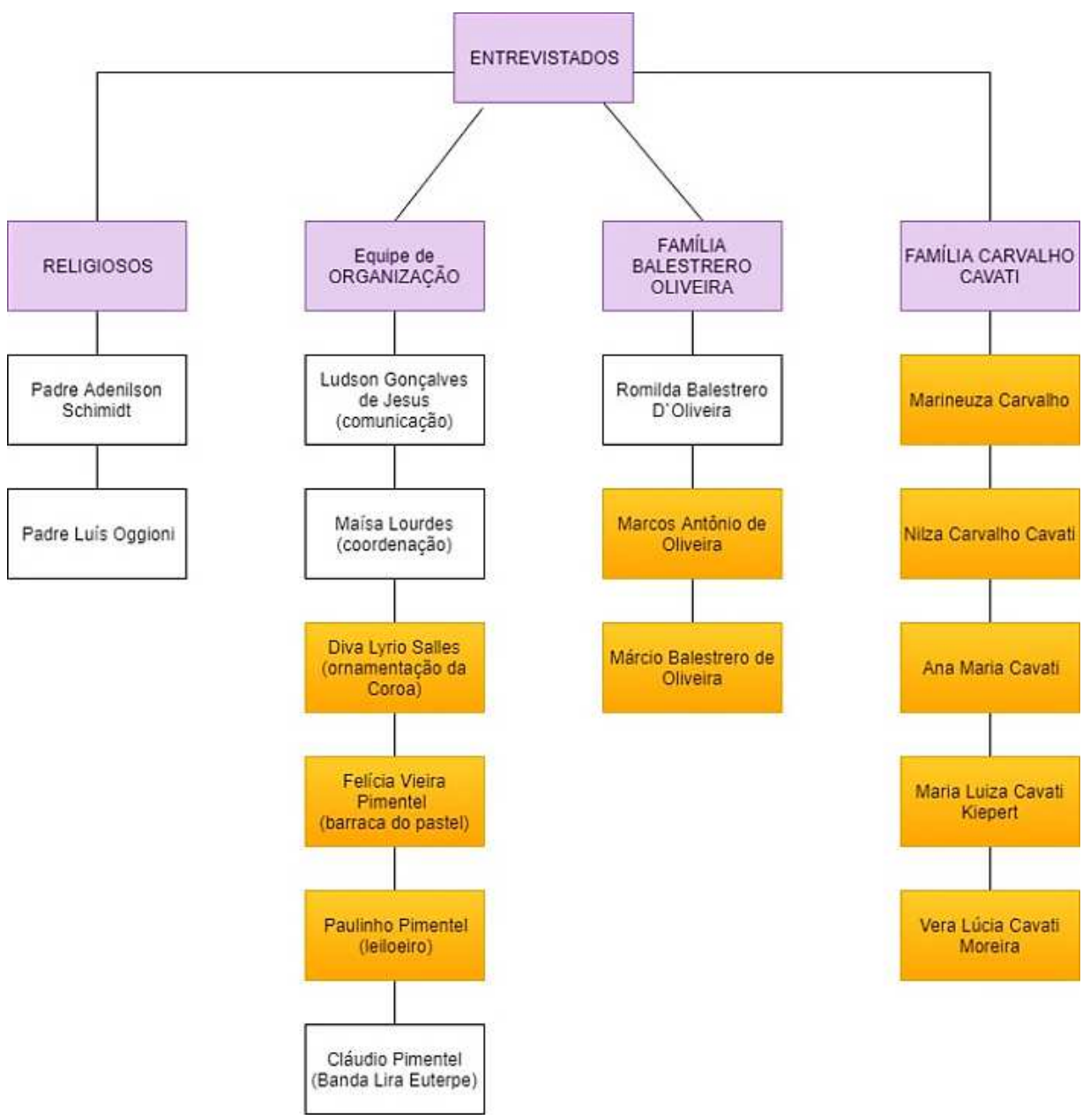

Fonte: Elaboração própria (os entrevistados destacados em amarelo já atuaram como imperadores ou imperatrizes do Divino na Festa)

\section{OS LUGARES DA FESTA}

Entre os lugares da Festa do Divino em Viana, destacamos, primeiramente, a Igreja Matriz Nossa Senhora da Conceição. De acordo com Balestrero (2012), a Igreja Matriz Nossa Senhora da Conceição foi construída entre os anos de 1815 a 1817, tornando-se um dos mais belos templos nas terras brasileiras (Saint-Hilaire, 1974, p. 233). A edificação foi parcialmente destruída num incêndio que ocorreu em março de 1848 (Balestrero, 2012, p. 121). Após o incêndio, uma de suas torres foi reconstruída em estilo diferente do original. Em 1860, 
D. Pedro II visitou o povoado - segundo Rocha (2008), havia uma comissão local instituída com o intuído de preparar a recepção ao imperador e era formada por autoridades locais e alguns fazendeiros. No ano de 1983, a Igreja Matriz Nossa Senhora da Conceição foi reconhecida como patrimônio cultural estadual, sendo tombada pelo Conselho Estadual de Cultura (CEC). Em sua resolução n ${ }^{\circ}$ 03/83, a edificação foi inscrita no Livro do Tombo Histórico sob o número 30, folhas $3 v$ e 4 . O documento em questão oficializou o tombamento da igreja e de seu entorno, integrando-os ao Patrimônio Histórico e Artístico do Estado do Espírito Santo.

Durante os dias em que ocorre a Festa do Divino em Viana, a igreja recebe ornamentação especial em seu interior e, eventualmente, nas esquadrias da parte frontal. No pátio externo da igreja, bem de frente à fachada principal, é hasteada a bandeira vermelha com a simbologia do Espírito Santo para sinalizar o tempo do Divino na localidade.

Outro espaço que recentemente passou a compor o conjunto estrutural da Festa do Divino em Viana é o "quarto da imperatriz". O referido local teve sua primeira montagem durante a Festa de 2017 e foi novamente montado no ano seguinte. Portanto, podemos inferir que se trata de uma (re)invenção ${ }^{5}$ da tradição da Festa (Hobsbawn, 2014). O quarto da imperatriz é montado com mobiliário, tecidos e objetos requintados, e seu principal objetivo é servir como cenário para aqueles que desejem fotografar e guardar uma lembrança da Festa do Divino, num espaço preparado especialmente para a ocasião.

O pátio lateral da igreja é o lugar escolhido para a realização da quermesse. Nele é montada toda a estrutura de apoio para os festejos: palco para viabilizar a apresentação de atrações culturais, praça de alimentação com mesas e cadeiras e barraquinhas para comercialização de comidas e bebidas.

Além da igreja, do pátio da igreja e do quarto da imperatriz, ressaltamos a importância das casas dos imperadores como espaços de consolidação da Festa, servindo de território sagrado na concretização dos rituais. A decoração e a bandeira do Divino, quando presentes em alguma edificação, sinalizam que aquele espaço, durante o período da Festa, também assume uma ligação com o sagrado.

\footnotetext{
${ }^{5}$ A reinvenção de uma tradição, ao considerarmos o conceito de Hobsbawn (2014), seria o acréscimo ou exclusão de rituais ou práticas simbólicas capazes de serem incorporados aos comportamentos por meio da prática da repetição, ou seja, são capazes de referenciar uma "continuidade em relação ao passado". Hobsbawn (2014) destaca que a repetição de uma "tradição inventada", ou neste caso, "reinventada" se presta ao trabalho de conservar velhos costumes em situações novas ou, até mesmo, de justificar a utilização de novos modelos para velhas finalidades. Para ele, tratase de uma apropriação de elementos do passado com o objetivo de perpetuá-los no presente.
} 
Para além da referência como espaço físico pertencente às cerimônias religiosas, as casas dos imperadores experimentam modificações em seu funcionamento, principalmente no que se refere às questões de ordem espiritual, pois o imperador e a imperatriz são considerados os representantes da divindade durante a Festa. As casas do imperador e da imperatriz, no decorrer das procissões, servem como ponto de partida ou de chegada. Em frente às fachadas dessas residências são montados pequenos altares que servem de apoio para os momentos de oração. As procissões também envolvem outros lugares de Festa: a igreja e as ruas do entorno. As ruas do entorno assumem um importante papel durante os festejos, pois atuam como um elo entre as casas dos imperadores e a Igreja Matriz Nossa Senhora da Conceição.

Assim como as casas dos imperadores, as ruas também são variáveis e a cada ano são modificadas de acordo com o sorteio do imperador e da imperatriz. De certa forma, existem algumas ruas de acesso à Igreja Matriz que sempre se repetem no trajeto dos cortejos. Quando o imperador ou a imperatriz residem longe da Igreja Matriz, seja na cidade de Viana ou fora dela, é escolhida a casa de algum amigo ou parente para servir como apoio durante os festejos e, assim, a procissão se dirige até lá para o cumprimento do ritual.

As casas das famílias que recebem as bandeiras dos dons do Espírito Santo também estão incluídas entre os lugares da Festa. Ao todo são sete famílias escolhidas pela equipe de organização, e cada uma delas recebe a bandeira de um dom diferente: fortaleza, sabedoria, ciência, conselho, entendimento, piedade e temor de Deus. O imperador e a imperatriz também recebem bandeiras específicas, entretanto, não estão relacionadas aos dons do Espírito Santo.

As bandeiras são hasteadas nas fachadas das casas, simbolizando a presença do sagrado naquele local. Algumas famílias também fazem decorações alusivas ao Divino junto às bandeiras e preparam altares no interior das residências para receber as equipes da Igreja. Durante a semana seguinte, cada casa recebe a visita num dia diferente e, na ocasião, são realizadas orações junto das famílias anfitriãs. Um dos entrevistados relata que essa foi uma das principais modificações positivas que já observou na realização da Festa e acredita que a inserção da procissão das bandeiras e das orações realizadas nas casas das famílias seja uma espécie de resgate espiritual promovido pela Festa (L. Gonçalves de Jesus, comunicação pessoal, 25 de novembro 2017) ${ }^{6}$.

\footnotetext{
${ }^{6}$ As entrevistas foram feitas por Fabiene Passamani Mariano.
} 
As residências escolhidas para receber as orações e as bandeiras dos dons estão sempre situadas no caminho entre a casa do imperador e a igreja. No domingo de Pentecostes, durante o retorno da procissão que vai buscar o imperador, o cortejo passa nas casas das famílias para que elas se unam à procissão portando as bandeiras dos dons até a igreja. Chegando lá, em ato solene, as famílias conduzem suas bandeiras até o altar e lá as depositam num local próprio.

\section{OS PERSONAGENS DA FESTA}

Os personagens de maior relevo na Festa são o imperador e a imperatriz. Atualmente são escolhidos por meio de sorteio, realizado no último dia da Festa, o que coloca todos os interessados em posição de igualdade, independentemente da situação financeira. Ao permitir a atuação de pessoas menos abastadas em posições de destaque, a Festa consagra a criação de novas posições hierárquicas, mesmo que temporárias, naquela comunidade.

Entre as principais atribuições dos imperadores está a captação de donativos, recursos financeiros e trabalho voluntário. Além disso, os imperadores simbolizam a presença da divindade e, por conta disso, ocupam posições de destaque durante os rituais religiosos. Entretanto, a nossa pesquisa apontou para uma séria questão de controle social no que diz respeito à organização da Festa. Os imperadores, apesar de responderem pela organização dos festejos, não gozam de autonomia para decidir questões que fujam do modelo básico seguido há anos pela comunidade. Tanto na parte religiosa, quanto na parte secular, eles são apresentados a um script e este deve ser seguido sem maiores questionamentos.

Essa é uma característica que distancia a Festa do Divino que ocorre em Viana da Festa do Espírito Santo que ocorre nos Açores, onde os imperadores gozam de total autonomia na condução dos festejos, enquanto os religiosos ficam restritos à execução de alguns rituais, como as missas, as bênçãos dos alimentos e a cerimônia de coroação.

Sobre esse aspecto, alguns fazem uma crítica muito interessante acerca do papel dos imperadores na conjuntura atual da Festa e do controle imposto pela Igreja: "hoje eles são apenas dois elementos, dois símbolos. Assim como o mastro com a pomba não é o Espírito Santo e a coroa não é a igreja... eles apenas representam"; "Por mais que se decida sempre num grupo maior, eles não têm nenhuma autonomia. A própria estrutura religiosa é uma estrutura que os elimina"; "Se a vontade dos imperadores não estiver alinhada com o que a equipe da comunidade acredita ser o certo, eles [equipe] decidem e pronto. Então, para quê 
existem o imperador e imperatriz?" (L. Gonçalves de Jesus, comunicação pessoal, 25 de novembro 2017). No entanto, outras pessoas explicam o porquê dessa situação: "Se eles [os imperadores] tiverem autonomia, podem agredir ou fazer coisas que conflitam com a orientação da igreja. Por exemplo, cito o caso da banda 'Soxotão', quando o ministério público mandou que ela fosse retirada da programação. A questão não era somente pelo nome da banda, mas porque já ocorreram várias brigas em cima do palco. Eles falam muitos palavrões" (M. L. da Silva, comunicação pessoal, 25 de agosto 2018).

O imperador e a imperatriz ocupam posição de destaque durante os rituais religiosos da Festa. Nas procissões, eles saem à frente do cortejo vestindo roupas formais, mas sem nenhum traje específico. Portar os símbolos do Divino durante os rituais religiosos da Festa também faz parte dos encargos deles. A imperatriz conduz a coroa do Divino, enfeitada com laço de fita e rosas vermelhas. O imperador, por sua vez, carrega o mastro com a bandeira, encimado por uma pombinha branca. Nesse mastro são amarradas tiras de fitas coloridas em agradecimento aos pedidos alcançados pelos devotos do Divino Espírito Santo. Na organização dos festejos do Divino não existem funções pré-definidas de acordo com o gênero. O que pode ser observado claramente é que as tarefas são divididas de forma igualitária entre homens e mulheres. A escolha das funções geralmente se baseia na afinidade do serviço a ser realizado.

Os imperadores, juntos ou separados, começam a percorrer a cidade e a zona rural em busca de donativos já alguns meses antes da Festa. Eles visitam comércios e empresas em busca de patrocínios, bem como solicitam ajuda financeira aos familiares, amigos e vizinhos. O sacrifício do imperador (ou da imperatriz) é baseado numa crença compensatória, ou seja, no futuro, toda dedicação e/ou investimento financeiro serão recompensados pela divindade em forma de bênçãos. Entretanto, essa formulação ideológica pode esconder outros aspectos de interesse secular daqueles que assumem o encargo: "[...] uma festa rica e farta, serviria, para aumentar-lhes o prestígio e reforçar suas relações com dependentes, parentes e vizinhos" (Zaluar, 1983, p. 73).

A família Carvalho Cavati possui uma história de engajamentos na organização da Festa e apresenta uma grande ocorrência de imperadores e imperatrizes do Divino em sua história. Marineuza Carvalho relembra que o fato de participar da Festa como imperatriz do Divino foi decisivo para que ela "tomasse gosto pela coisa" e, desde então, sua dedicação aos festejos passou a ocorrer de forma mais efetiva e regular. Atualmente, ela se apresenta como a responsável pela montagem e funcionamento da barraca de doces durante a Festa. Sobre a projeção 
da participação de seus filhos nos festejos do Divino, Marineuza acredita que eles continuarão colaborando na organização, todavia, não enxerga a possibilidade de candidatura ao encargo de imperador ou imperatriz, pelo menos enquanto são jovens. Ela recorda que também só despertou essa vontade quando já tinha por volta de 57 anos (M. Carvalho (Tia Neuzinha), comunicação pessoal, 29 de agosto 2018).

Quando indagada sobre sua motivação para concorrer ao encargo de imperatriz do Divino, Nilza Carvalho respondeu: "Parece que é o dom do Espírito Santo que chama a gente. (...) Minha motivação foi a devoção, a fé" (N. Carvalho Cavati, comunicação pessoal, 30 de agosto 2018). Das cinco filhas de Nilza Carvalho, três já atuaram como imperatrizes do Divino: Vera Lúcia Cavati, em 1979; Maria Luiza Cavati, em 2007, e Ana Maria Cavati, no ano de 2015. As outras duas filhas do casal, Vanilza Cavati e Valéria Cavati, apesar de não terem atuado como imperatrizes na Festa do Divino, afirmam que já se inscreveram no sorteio, entretanto, ainda não foram contempladas. Além das filhas, um dos netos, filho de Vanilza Cavati, já atuou como imperador do Divino durante sua pré-adolescência, no ano de 2008.

Vera Lúcia Cavati, foi a primeira a atuar com imperatriz na Festa do Divino. Isso ocorreu enquanto ainda era criança e foi seu pai que colocou seu nome para o sorteio. Ao ser sorteada, ela teve que assumir a função, porém, a condução da organização dos festejos foi de responsabilidade de seu pai. (V. L. Cavati Moreira (Verinha), comunicação pessoal, 19 de junho 2018). A sua irmã, que atualmente coordena os ministros da Eucaristia e atua junto de seus familiares na barraca que prepara porções de carne na chapa com batatas fritas, também acentua que a tradição religiosa em sua família foi decisiva para sua participação na Igreja e também na Festa do Divino (M. L. Cavati Kiepert, comunicação pessoal, 30 de agosto 2018). Outra irmã, Ana Maria Cavati, também presta serviços voluntários na igreja e na organização da Festa - foi a última das irmãs a atuar como imperatriz na Festa do Divino em Viana, sendo sorteada para organizar a Festa de 2015. Apesar de ter sido sorteada pela primeira vez no final da década de 1970, naquela época não foi possível assumir as funções de imperatriz, devido a seu adiantado estado de gravidez. Ela foi representada por sua irmã. Quando perguntamos sobre sua motivação para atuar como imperatriz do Divino, Ana Maria respondeu que suas principais influências religiosas foram seu pai e sua avó materna (A. M. Cavati, comunicação pessoal, 3 de setembro 2018).

A segunda família pesquisada, Balestrero de Oliveira, também é marcada pela ocorrência de imperadores do Divino em sucessivas gerações. Cabe ressaltar que 
os entrevistados dessa família, apesar de atualmente não residirem mais na cidade de Viana, continuam participando ativamente da organização da Festa do Divino.

No histórico da família Balestrero de Oliveira, o primeiro a exercer o encargo de imperador do Divino foi Heribaldo Lopes Balestrero, seguido por sua irmã Aidê, que atuou como imperatriz na Festa do Divino em Viana. A partir daí, os filhos e os netos continuaram o legado de participar da organização da tradicional Festa. Romilda Balestrero D’Oliveira tentou por várias décadas, mas nunca foi sorteada para o encargo de imperatriz, entretanto, seu marido Cloves de Oliveira e seus filhos Marcos e Márcio atuaram como imperadores do Divino. Márcio foi imperador por duas vezes: a primeira, no ano de 1979, junto com Vera Cavati e a segunda, em 2006.

De acordo com Romilda, o ato de participar da Festa do Divino e ajudar na sua organização faz parte de sua história familiar. Marcos Antônio Oliveira, filho dela, ressalta que não pensava em "ser imperador do Divino", mas que sempre participou da Festa para ajudar, pois achava que era muita "trabalheira", principalmente para ele, que sempre foi empresário. Sobre o sorteio que o conduziu ao encargo de imperador do Divino, realizado no ano de 2011, Marcos fez um relato muito emocionado: "Chega um dia que você é escolhido e aí as forças que conduzem a isso, a gente não sabe de onde vêm, mas devem vir dos astros, de questões espirituais" (M. A. Oliveira, comunicação pessoal, 14 de agosto 2018). Seu irmão mais novo, Márcio, participou como imperador do Divino nos anos de 1979 e de 2006. Durante a organização da Festa de 2006, Márcio percorreu praticamente todas as fazendas do município na companhia de Otomar Cavati, visando arrecadar prendas para o leilão: “(...) para minha surpresa, acho que não tivemos nenhuma resposta negativa". Além de muitas doações, Márcio relata que conseguiu diversos brindes para a "Ação entre amigos"7 e, inclusive, a música ao vivo para o almoço de domingo. E acrescenta: "de lá para cá, senti que a Festa voltou a tomar a sua proporção anterior, e, assim, a Festa a cada ano tem sido melhor". Para Márcio, angariar fundos para a Igreja é um dos objetivos da Festa do Divino, porém, em seu entendimento, o objetivo maior seria envolver as famílias e que estas entendam o significado da devoção ao Espírito Santo e passem a participar ativamente das atividades da Igreja (M. Balestrero de Oliveira, comunicação pessoal, 20 de agosto 2018).

\footnotetext{
${ }^{7}$ Uma espécie de rifa em que a pessoa compra um bilhete e esse número dá o direito a concorrer ao sorteio de vários brindes, por exemplo: aparelhos de televisão, smartphones, tablets ou, até mesmo, prêmios em dinheiro.
} 
Algumas pessoas da comunidade se colocam como colaboradores cativos da Festa e, a cada ano, basta a visita do imperador ou da imperatriz para que a doação seja confirmada. Quanto a isso, o leiloeiro oficial da Festa do Divino há mais de 25 anos, acrescenta: “[...] eu já sei as pessoas com quem podemos contar. Tem umas pessoas que a ajuda é certa. É só ir lá. Eu já conheço! Um ajuda o outro e isso se torna uma corrente" (P. R. Pimentel (Paulinho Pimentel), comunicação pessoal, 27 de agosto 2018).

Atualmente, o sucesso de uma Festa do Divino está diretamente vinculado à movimentação financeira que essa proporciona. Uma Festa "forte" depende de um imperador ou uma imperatriz "forte", ou seja, "[...] uma pessoa mais conhecida, que corre atrás, que tem a situação (financeira) boa. Na época da Festa, a gente precisa conseguir carro... aí, se o imperador não tiver carro, sempre precisamos recorrer a alguém. As pessoas que têm boa situação e conhecimento acabam conseguindo as coisas de forma mais fácil. Quando o imperador é fraco, a festa é fraca. Essa é a verdade!"' (P. R. Pimentel (Paulinho Pimentel), comunicação pessoal, 27 de agosto 2018).

Entre os entrevistados para esta pesquisa, muitos entendem que a questão financeira deveria ser uma preocupação secundária, entretanto, não tem sido. $\mathrm{O}$ sucesso da Festa deveria estar relacionado às questões espirituais, visando à manutenção de sua essência religiosa. No entanto, a preocupação atual está centrada, essencialmente, no lucro. Por esse motivo, alguns passaram a frequentar somente a parte religiosa, pois não enxergam motivos para vivenciar a parte secular dos festejos (L. Gonçalves de Jesus, comunicação pessoal, 25 de novembro 2017).

Outra questão polêmica, que se repete em diversos depoimentos desta pesquisa, é a necessidade de instituir pré-requisitos às candidaturas para os encargos de imperador e imperatriz. No recorte temporal pesquisado, não há registros de quaisquer exigências formais àqueles que se candidatam aos encargos. Muito pelo contrário, para concorrer ao sorteio basta se inscrever.

Essa falta de critérios tem gerado certo desconforto entre os integrantes mais conservadores da comunidade e isso foi citado em algumas entrevistas, pois os participantes consideram que os encargos de imperador e imperatriz exigem muita responsabilidade de quem os assume. Esses entrevistados afirmam que, sem o estabelecimento de pré-requisitos, existe grande possibilidade de que pessoas sem vivência religiosa e/ou vínculos com a comunidade assumam o encargo por impulso e posteriormente não realizem um bom trabalho.

A inscrição dos candidatos pode ser feita até poucos minutos antes da hora do sorteio - que ocorre por volta das 20 horas, quando grande parte do púb- 
lico já se encontra em estado de euforia. Esse clima festivo se justifica tanto pela programação dos festejos, como também pelo consumo de bebidas alcoólicas por alguns participantes: "Hoje em dia está muito solto. Eles não colocam os prérequisitos, mas depois ficam reclamando quando pessoas que não entendem nada da Festa se candidatam e são sorteadas" (F. Pimentel Vieira, comunicação pessoal, 3 de outubro 2018).

Um exemplo desse fato pode ser o sorteio realizado na Festa de 2018. Na ocasião, o imperador sorteado para o ano de 2019, Julio Cezar Klaczok, não era praticante dos preceitos católicos e, por consequência desse fato, também não havia cumprido os principais sacramentos do Catolicismo, entre eles o Batismo e a Primeira Eucaristia. Isso ilustra a amplitude social da Festa em ultrapassar as barreiras de sua fundamentação essencialmente religiosa: trata-se de uma festa comunitária na qual é possível que pessoas de diversas denominações religiosas partilhem dos festejos, principalmente das celebrações seculares. Nesse sentido, cabe também ressaltar a importância histórica e política dessa Festa que, anualmente, recebe o apoio do Poder Público Municipal ${ }^{8}$ e a visita das autoridades locais. No passado, a Festa do Divino Espírito Santo era oficialmente incluída no orçamento municipal. Desta forma, a Prefeitura estava oficialmente autorizada a repassar recursos financeiros para auxiliar a realização dos festejos, conforme versa a Lei No 854/1976 da Câmara Municipal de Viana9.

Durante as entrevistas, foi unânime o entendimento da relação direta entre a atuação do padre local e o sucesso dos festejos, sendo ele responsável pela execução dos rituais religiosos e coordenação geral na equipe de organização, com o poder de decisão e a palavra final. Em suma, quanto maior esse envolvimento, maior se torna a admiração da comunidade por seu trabalho: "O padre Luís toma a frente das coisas. Ele ajuda em tudo e frita até pastel. Todo mundo gosta disso! Talvez seja porque ele veio do interior e, dessa forma, entende como funciona isso nas cidades pequenas" (F. Pimentel Vieira, comunicação pessoal, 3 de outubro 2018). O perfil do padre faz toda diferença na organização e no resultado final da Festa. No caso da angariação de donativos, alguns padres acompanhavam os imperadores nessa demanda e, assim, "a coisa rendeu mais, as pessoas abraçaram mais a causa. A visita do padre faz muita diferença, assim como o resultado da própria Festa faz toda diferença. A Festa dá mais gente. A gente escuta os comentários" (M. L. Cavati Kiepert, comunicação pessoal, 30 de agosto 2018).

\footnotetext{
${ }^{8}$ Atualmente, a Prefeitura apoia os festejos do Divino através da contratação de algum tipo de serviço especializado, por exemplo: palco, sonorização, atração musical, toldos, gráfica etc.

9 Disponível em http://www3.camaraviana.es.gov.br/Arquivo/Documents/legislacao/html/L8541976.html. Acesso em 08 de dez. 2018.
} 
O envolvimento do padre é um fator que influencia diretamente nos resultados e isso ocorre porque a figura do religioso atrai um número bem maior de pessoas, tendo em vista sua representatividade junto à comunidade católica: "tem gente que só vai à igreja se o padre estiver lá e esse pensamento também se repete durante a Festa do Divino" (C. Pimentel, comunicação pessoal, 9 de outubro 2018).

Com relação à importância do papel desempenhado pelos padres na história da Festa do Divino em Viana, vale a pena mencionar que no ano de 1950 a tradição foi interrompida pelo vigário da época, o padre Venâncio Toller (Balestrero, 2012, p. 99). Entretanto, essa interrupção não durou muitos anos: “em 1953, assistimos à Festa do Divino em Viana e, em 1960, fazíamos referência a ela, quando divulgamos, através de A Gazeta (edição de 05 de junho) ${ }^{10}$, a notícia do programa da Festa, que naquele dia se estava realizando" (Neves, 2008, p. 53). Acerca dessa interrupção, a maioria dos entrevistados desconhecia o fato, mas, ao serem questionados, emitiram opiniões de resistência e revolta quando indagados sobre o que aconteceria se, nos dias de hoje, algum padre quisesse proibir a realização da Festa do Divino em Viana. Atualmente, mesmo que o padre não queira sua realização, isso não será permitido pela comunidade, pois “a Festa já se tornou uma tradição no município" (A. M. Cavati, comunicação pessoal, 3 de setembro 2018). Contudo, alguns confirmaram o excessivo poder de decisão dos padres no passado: "Não teve a festa porque o padre não quis. Ele tinha participado da Guerra (...). Ele era meio louco e não podia ouvir tiros. Se alguém soltasse uma bomba, ele se metia debaixo de onde estivesse: debaixo das mesas, das camas. Quando ele não queria, não tinha festa, mesmo que o pessoal da Igreja quisesse. Eu acho que isso ocorreu mais de uma vez" (R. N. Balestrero D'Oliveira, comunicação pessoal, 15 de maio 2018).

Ao ser questionado sobre a postura adotada pelo religioso que proibiu os festejos do Divino em Viana, padre Adenilson Schimidt ressalta: "Somos devidamente formados e orientados para que possamos nos inserir no contexto da comunidade. Eu acho que hoje em dia, isso seria muito pouco provável de acontecer. Poderia até ocorrer alguma divergência sobre qual artista ou banda iria se apresentar, mas, proibir a Festa seria um ato arbitrário. Antigamente para os padres da época existia aquela ideia de que só havia dois representantes da lei: o padre e o delegado. Hoje a sociedade não permite mais isso. Ela é mais atuante e democrática” (Pe. A. Schimidt, comunicação pessoal, 19 de agosto 2018).

\footnotetext{
${ }^{10}$ A matéria do jornal citada por Neves (2008) traz informações gerais sobre a Festa do Divino em Viana e sobre a realização de Festas do Divino com características similares em outros municípios do Espírito Santo (Marataízes, Iconha e São Mateus).
} 
De uma forma geral, os entrevistados concordam que, atualmente, o poder do representante religioso tem que vir acompanhado de bom senso e respeito com a cultura local. Caso contrário, esse comportamento inadequado poderá instigar diversos conflitos com a comunidade.

Além dos personagens da Festa já apresentados, também existe uma equipe formada especialmente para auxiliar os imperadores e o padre na organização dos festejos, se encarregando na busca de patrocínios, na montagem e divulgação da programação, na organização das barracas da quermesse, na visita às propriedades rurais para angariar prendas para o leilão, entre outras atividades. Além disso, a equipe também conta com pessoas que auxiliam no preparo e na execução dos rituais religiosos da Festa.

Entre os integrantes da equipe de organização, merece especial destaque a figura do leiloeiro. Há aproximadamente 25 anos, Paulo Roberto Pimentel atua nessa função. Foi já imperador do Divino no ano de 2003. Além de conduzir o leilão, ele também se envolve na organização geral da Festa. Ele relata que, por muitos anos, tem acompanhado os imperadores durante as visitas às propriedades rurais para solicitar as doações e para buscar as prendas na véspera da Festa. Segundo ele, os fazendeiros e pequenos agricultores do município sempre estão dispostos a doar animais e produtos cultivados em suas propriedades. Paulo Pimentel afirma que gosta muito de realizar o leilão, mas que gostaria que alguém começasse a se interessar pelo assunto, que deveria ser repassado aos mais jovens: "Eu sempre digo no final do leilão que isso é uma tradição, que a gente tem que começar com os filhos e netos, com os sobrinhos e outros parentes também (...) Porque um dia isso acaba. Eu acho que as pessoas só querem o forró, o baile... Mas, mesmo tendo isso tudo, o leilão tem que ter um leiloeiro para animar". (P. R. Pimentel (Paulinho Pimentel), comunicação pessoal, 27 de agosto 2018). Ele ainda apresenta uma interessante reflexão a respeito da redução no número de frequentadores da Festa, reparando que, atualmente, muitos eventos competem com a Festa do Divino e isso acaba dividindo o público.

Em suma, os principais personagens da Festa, apesar de modificados a cada ano, não perdem características essenciais - se apresentam como elementos singulares que se complementam no desenvolvimento dos rituais e dos diversos acontecimentos que compõem os festejos do Divino na cidade de Viana. 


\section{OS ACONTECIMENTOS DA FESTA}

Mesmo que alguns elementos sejam alterados a cada ano, a estrutura ritualística ${ }^{11}$ da Festa é praticamente fixa e costuma se repetir, salvo raras exceções, quando algumas atividades foram modificadas, substituídas ou até suprimidas dos rituais. A relevância da Festa do Divino, em seus elementos recreativos, estéticos e religiosos se localiza na inter-relação entre a celebração religiosa e a concepção de festa. Segundo Durkheim (1989), essa inter-relação aproxima as pessoas, promovendo um estado de "efervescência coletiva" - uma energia emocional compartilhada durante o ato religioso e/ou festivo. Na celebração do Divino Espírito Santo, a categorização dos rituais entre sagrado e profano está presente nos festejos, demostrando certa complementariedade entre as duas categorias. Portanto, o fato de um evento ter músicas, danças e levar as pessoas a uma dimensão de convivência, não necessariamente deve ser considerado como algo inapropriado. Para o padre, o que acontece do lado de fora é uma continuidade do que é celebrado no templo e sua existência seria a prova da continuidade do aspecto religioso na vida social: "Sempre tivemos a preocupação em instruir, especialmente aqueles que estariam realizando os shows, para que evitassem certas músicas que pudessem depreciar alguém ou o próprio contexto do credo... não seria adequado cantar músicas que incitassem a violência ou a discriminação, por exemplo" (Pe. A. Schimidt, comunicação pessoal, 19 de agosto 2018).

Sobre as diferentes possibilidades de apreensão da Festa com relação à sua parte profana, convém destacar dois posicionamentos bastante antagônicos que foram revelados durante a pesquisa: Para alguns, mesmo considerando a parte sacra como a mais importante dos festejos do Divino, que acontece após os rituais religiosos algo bastante positivo, tendo em vista seu caráter fortalecedor de laços sociais naquela localidade: "A igreja fica totalmente diferente. Ela é toda enfeitada, mas, o que mais me chama atenção é que é um dia que reúne as pessoas. Não só dentro da igreja, mas também fora dela. Porque as pessoas que vêm para a missa continuam ali depois que ela termina. Aí tem o horário do almoço, momento em que todos se encontram. Pode até não ser um almoço partilhado, pois ele é vendido para levantar recursos para a igreja. Mas, você sente que ali existe a partilha, o encontro. Então, essa é uma parte muito importante. Depois vem o leilão e ele marca. Às vezes, tem pessoas que você fica sem encontrar por tanto tempo e aí acontece o reencontro. Tem as lembranças, muitas lembranças"

${ }^{11}$ Como estrutura ritualística da festa consideramos a realização de missas, procissões e festividades no pátio externo da igreja após os eventos religiosos. 
(V. L. Cavati Moreira (Verinha), comunicação pessoal, 19 de junho 2018); contudo, para outros a parte profana ou secular da Festa é totalmente dispensável fazendo com que a essência da Festa esteja se perdendo a cada ano com alguns tipos de atrações culturais, assim como o comportamento das pessoas, não condizendo com a atmosfera religiosa da Festa. Esses fatos fazem com que alguns participem apenas dos rituais religiosos, por considerarem que as atividades seculares (ou profanas), atualmente, não estão correspondendo ao sentido religioso que delas é esperado: "O profano designa a quebra do sagrado. (...) Mas, hoje eu falo que a festa profana é uma quebra de vínculo com o religioso. O que me incomoda é exatamente isso: você vai num open bar, você vai à festa profana do Divino e é a mesma coisa, comparando os elementos. Então, isso é um problema." (L. Gonçalves de Jesus, comunicação pessoal, 25 de novembro 2017). Mesmo que algumas opiniões apresentadas neste estudo sejam dissonantes, em geral, as narrativas da maioria dos entrevistados apontam para a valorização da complementaridade entre as duas esferas, sagrada e profana, presentes nos festejos do Divino em Viana.

Com a aproximação da data de realização da Festa, o envolvimento dos participantes se torna cada vez mais intenso e, durante sua realização, que dura aproximadamente uma semana, é onde notamos o ápice desse processo. Na semana anterior a esse ápice, acontece a "missa de envio dos festeiros" com a cerimônia de entrega das bandeiras dos sete dons do Espírito Santo, em que os imperadores recebem uma bênção especial do padre. As bandeiras são confeccionadas em tecido vermelho e possuem a imagem de uma pomba do Divino e a inscrição de um dos dons do Espírito Santo. Após recebê-las, as sete famílias levam-nas para suas residências e penduram-nas em suas fachadas. Durante a semana seguinte, algumas equipes da Igreja se organizavam para rezar nas casas dessas famílias e proferir orações relacionadas aos dons recebidos. Segundo Mariano (2012, p. 84): "De acordo com informações dos entrevistados, a procissão das bandeiras foi iniciada no ano de 2009 pela equipe de organização da festa, com o objetivo de 'incrementar' os rituais". O padre Adenilson relata que, entre os anos de 2004 a 2008, também resgatou uma antiga tradição da Festa: a passagem da bandeira no interior da igreja durante as celebrações religiosas (Pe. A. Schimidt, comunicação pessoal, 19 de agosto 2018). Entretanto, esse ritual atualmente já não existe mais em Viana. Dessa forma, percebemos que a inclusão e exclusão de rituais e simbologias é algo recorrente na Festa. Seu surgimento e sua permanência dependem diretamente daqueles que estão à frente da organização dos festejos. Nesse caso específico, após a saída do padre Adenilson de Viana, essa 
forma de inserção da bandeira nos rituais religiosos da Festa foi abandonada. Padre Adenilson também relatou que foi o responsável por outra modificação expressiva durante a celebração do Divino: a mudança de tríduo para novena. Recentemente, no entanto, o formato tríduo está sendo o mais utilizado devido à possibilidade de realizar uma festa mais compacta.

O sábado da véspera de Pentecostes é o dia dedicado à imperatriz, e os festejos se concentram no período noturno. Como primeiro compromisso ritual, acontece a procissão da imperatriz. Por volta das 19 horas, o imperador, acompanhado de um pequeno cortejo formado pelo padre, coroinhas, ministros da igreja e devotos, parte da Igreja Matriz em direção à residência da imperatriz. Durante a procissão, o imperador, portando a bandeira e a pomba do Divino, caminha em posição de destaque pelas ruas da cidade, enquanto a banda conduz a parte musical, entoando hinos em homenagem ao Divino Espírito Santo. Nos intervalos entre os cânticos, os participantes da procissão rezam orações.

Em frente à casa da imperatriz, geralmente é montado um pequeno altar para ser apoiada a coroa do Divino. A imperatriz aguarda a chegada do cortejo junto de seus familiares e vizinhos. Quando o cortejo chega ao destino, o imperador se coloca ao lado da imperatriz enquanto o padre profere uma oração. Finalizada essa etapa, os imperadores e o padre se posicionam a frente do cortejo para retornarem à igreja junto com os demais participantes da procissão.

A missa do sábado é semelhante às missas que ocorrem todas as semanas naquela igreja, não fosse a presença dos imperadores do Divino em posição de destaque próximo ao altar, bem como as pregações e cânticos relacionados ao Divino Espírito Santo. É comum que se convide padres e equipes de música de outras comunidades durante os festejos.

Finalizada a missa, os símbolos do Divino - coroa, bandeira e pomba do Espírito Santo - permanecem em destaque em frente ao altar da igreja, até que a mesma seja fechada. Após o fechamento do templo, por volta das 21 horas é iniciada a quermesse no pátio externo da igreja - um momento de convívio social em que todos se reúnem para apreciar as atrações culturais da Festa e consumir os produtos comercializados ${ }^{12}$ nas barraquinhas.

\footnotetext{
${ }^{12}$ Segundo Ludson Gonçalves, os valores cobrados nos alimentos deveriam ser mais justos, oferecendo algumas opções mais econômicas, principalmente para atender aquelas famílias mais numerosas e de baixa renda. Para ele, os preços praticados atualmente servem para limitar o público da Festa de acordo com os interesses financeiros da Igreja (L. Gonçalves de Jesus, comunicação pessoal, 25 de novembro 2017).
} 
A partir desse momento, o movimento no local torna-se significativo, tendo em vista que, além da movimentação de pessoas que estavam na missa, também chegam outras para participar apenas da parte secular da Festa. Esse público, que participa exclusivamente da quermesse, é formado por pessoas que, apesar de não frequentarem a Igreja Católica, apreciam a Festa do Divino por sua programação cultural, bem como pela socialização que os festejos possibilitam.

A programação cultural dos festejos é realizada num palco montado na lateral da igreja, com destaque para os shows de música sertaneja e de forró. Alguns participantes dançam durante as apresentações, enquanto outros permanecem sentados à mesa conversando, consumindo petiscos e bebidas.

Apesar da grande movimentação de pessoas, a parte secular se encerra no início da madrugada, pois, no domingo, as festividades do Divino se iniciam logo pela manhã e a equipe envolvida na organização dos festejos é praticamente a mesma em todos os dias de sua realização. O domingo da Festa do Divino é considerado o dia mais importante dos festejos. É o dia que o catolicismo celebra o Pentecostes, ou seja, a descida do Espírito Santo sobre os apóstolos de Jesus Cristo. A programação desse dia reúne os rituais mais elaborados da Festa. Alguns entrevistados relataram que, há algum tempo, a programação do domingo do Divino iniciava com uma alvorada festiva. Segundo eles, às cinco horas da manhã havia queima de fogos para anunciar a importância da data para aquela comunidade. Na Festa realizada no ano 2017, por ocasião dos 200 anos da celebração do Divino em Viana, foi realizada a alvorada festiva como forma de resgate de antigas práticas que não estão presentes na Festa atual. Entretanto, esse foi um caso isolado que não se repetiu no ano seguinte.

A programação inicia por volta das 9 horas da manhã, com a procissão do imperador. Dessa vez, a imperatriz é quem sai da igreja junto com o padre e os demais integrantes do cortejo e se dirige à casa do imperador. $\mathrm{O}$ cortejo sai da igreja junto com o padre, alguns coroinhas, ministros da Igreja e os devotos. A imperatriz sai à frente, portando a coroa do Divino enfeitada com laço de fita e rosas vermelhas. A procissão do domingo conta com um número consideravelmente maior de participantes em sua realização, assim como os demais rituais realizados nesse dia. Chegando à residência do imperador, a imperatriz se posiciona ao lado do imperador para ouvir as orações proferidas pelo padre. Geralmente, na fachada da casa do imperador, também é preparado um pequeno altar para sinalizar a importância do local como lugar sagrado do Divino. Terminadas as orações, o imperador e a imperatriz, acompanhados por seus familiares e vizinhos, posicionam-se junto ao cortejo para cumprir o trajeto da procissão. 
Durante o período de realização desta pesquisa, em algumas edições da Festa do Divino, no trajeto de retorno à igreja, o cortejo parava em frente às sete casas que receberam as bandeiras e ali era realizada uma breve oração. Ao final da oração, os membros das famílias se juntavam à procissão para trazer suas bandeiras de volta à Igreja e também para participar da missa. No entanto, nas últimas Festas, visando otimizar o tempo e reduzir a duração da procissão do domingo do Divino, o recolhimento das bandeiras deixou de ser feito dessa forma. Sendo assim, as famílias passaram a participar apenas de uma pequena procissão no início da missa, conduzindo suas bandeiras da entrada da igreja até o altar e depositando-as num suporte específico para essa finalidade.

Por se tratar de uma ocasião solene, a missa do Divino é repleta de acontecimentos diferenciados e dura cerca de duas horas e meia. A igreja alcança sua lotação máxima e algumas pessoas chegam a participar da missa se aglomerando ao redor da porta principal, das portas laterais e até mesmo do coro. Em algumas oportunidades, a missa do Divino chega a contar com a participação de autoridades religiosas, como bispos e ou arcebispos do Estado.

No dia da missa do Divino, a Igreja Matriz recebe uma decoração especial e diferenciada, confeccionada com flores em tons de vermelho e branco, além de paramentos de mesa e púlpito decorados com a simbologia do Divino Espírito Santo.

Alguns devotos permanecem na igreja após o término da celebração com o objetivo de tocar nas insígnias do Divino e ali fazer suas preces. Somente nesses momentos é possível se aproximar desses objetos, pois, fora do período de realização da Festa, eles ficam guardados e só voltam a ser expostos no ano seguinte. Após a saída de todos os fiéis do interior da igreja, o templo é fechado e assim permanece até o final dos festejos.

No pátio externo é montada uma pequena praça de alimentação com o auxílio de toldos, mesas e cadeiras. Além das comidas que comumente são comercializadas nas barraquinhas (pastel, caldo de cana, cachorro quente, porções de carne e batatas fritas), também é servido o almoço comunitário. A refeição ${ }^{13}$, vendida ao preço de dez reais, é servida em marmitas ou em formato de prato-feito.

Alguns dos entrevistados mencionaram que, no passado, o almoço era partilhado entre todos os participantes da Festa, sem a necessidade de qualquer tipo de pagamento. Essa característica nos remete às origens dos festejos nos Açores, onde, até hoje, todos podem se servir gratuitamente em todas as refeições cerimoniais. Sobre suas lembranças de como aconteciam as refeições da Festa no

${ }^{13} \mathrm{O}$ cardápio pode variar um pouco de um ano para outro, mas, geralmente é composto por arroz, feijão, macarrão, farofa, carne de boi ou de frango e algum tipo de salada. 
passado, aparecem os comentários: "[...] no domingo tinha almoço de graça para todo mundo..." (F. Pimentel Vieira, comunicação pessoal, 3 de outubro 2018); "teve uma época em que a família da imperatriz fazia a comida e eles doavam. Ninguém comprava, o almoço era doado" (M. L. da Silva, comunicação pessoal, 25 de agosto 2018). Atualmente, todos os ingredientes necessários ao preparo do almoço são provenientes de doações da comunidade e toda renda resultante da comercialização dos pratos é revertida para a Igreja.

Durante o horário do almoço, são iniciadas as apresentações culturais da Festa. Geralmente, ocorrem apresentações musicais para ambientar aqueles que permaneceram na Festa após o término da missa. Além do almoço, as barraquinhas também iniciam a comercialização de produtos diversos. A programação dos festejos continua com apresentações de grupos de dança e outras atrações musicais até por volta das 15 horas, quando é iniciado o leilão - um dos pontos altos da Festa e uma das atrações que reúne o maior número de pessoas. Durante a realização do leilão, muitos proprietários rurais do município se reúnem para tentar arrematar os produtos e os animais disponíveis. Entre os doadores de animais, principalmente dos garrotes, é comum a tentativa de arrematar os lances e levar seu animal de volta para casa.

Com relação ao número de animais doados, o leiloeiro relata que, quando começou a conduzir o leilão, a arrecadação de bovinos ficava numa média entre 8 a 10 cabeças. De uns dez anos para cá, o leilão praticamente dobrou a quantidade de animais recebidos em doação. A arrecadação de animais e demais itens está diretamente ligada ao carisma e ao envolvimento dos imperadores. Todos os recursos financeiros provenientes das arrematações do leilão também são destinados exclusivamente à Igreja Matriz: “[...] ao final da Festa, a igreja faz a prestação de contas para registrar o valor da arrecadação. Tem Festa que gera um lucro de 20, 40, 50 mil reais... Com esse dinheiro são realizadas obras como aquela de ampliação do Centro Pastoral. O dinheiro também pode ser investido em melhorias na infraestrutura da igreja e do seu entorno" (P. R. Pimentel (Paulinho Pimentel), comunicação pessoal, 27 de agosto 2018).

Finalizados o leilão e as apresentações musicais, todas as atenções se voltam para o palco, aguardando a realização do sorteio da "Ação entre amigos". O padre e alguns integrantes da equipe sobem ao palco para realizá-lo. Logo depois se inicia o sorteio dos imperadores que irão organizar a Festa do ano seguinte. Os interessados em participar desse sorteio podem se inscrever até minutos antes de sua realização. Trata-se de um ritual carregado de simbologia e emoção. De acordo com Mariano (2012), “Todas as pessoas podem participar do sor- 
teio e para isso, basta formalizar esse desejo aos organizadores da Festa. Os nomes de todos os candidatos são colocados numa espécie de saco de tecido e, em outro recipiente são colocados outros papéis na mesma quantidade, sendo um papel com a palavra imperador ou imperatriz e todos os outros em branco. Para saber quem será o sorteado (a), tira-se o nome de uma pessoa de um lado e logo em seguida é tirado o outro papel, até que o nome imperador ou imperatriz apareça" (Mariano, 2012, p. 78).

O sorteio dos imperadores marca simultaneamente dois momentos de extrema importância para a Festa do Divino Espírito Santo em Viana. Trata-se do encerramento oficial da Festa em curso e o início de um novo tempo de Festa. É o momento em que novos personagens, novas ideias, enfim, novos ânimos se apresentam para a continuação dessa tradição cultural e religiosa.

Entretanto, alguns depoimentos apontaram que, no passado, a Festa não terminava dessa maneira, e sim com a realização de um ritual muito apreciado pela comunidade: a terceira procissão ou, procissão final: "além das duas procissões que se faz até hoje, no final da festa também tinha a procissão da tarde. (...) Era uma procissão muito bonita que terminava na igreja com a benção do Santíssimo. Para falar a verdade, eu acho que deveria continuar terminando a Festa assim. Hoje termina no palco" (N. Carvalho Cavati, comunicação pessoal, 30 de agosto 2018); "Antigamente tinha a procissão final. (...) passavam nas ruas em volta da igreja e depois retornavam para a bênção do Santíssimo e o sorteio dos novos imperadores. A Festa começava e terminava de uma maneira religiosa" (M. Carvalho (Tia Neuzinha), comunicação pessoal, 29 de agosto 2018); "Ela acontecia na parte da tarde, com os imperadores, os fiéis e a banda. (...) A festa terminava na igreja. Eu não sei por que isso mudou" (C. Pimentel, comunicação pessoal, 9 de outubro 2018). De acordo com as narrativas, a procissão de encerramento reunia todos os participantes da Festa. $\mathrm{O}$ ato de iniciar e terminar a Festa dentro da igreja, de acordo com os entrevistados, refletia um maior compromisso religioso entre os participantes.

\section{CONSIDERAÇÕES FINAIS}

A Festa do Divino é uma herança cultural e religiosa dos imigrantes açorianos - fundadores de Viana, que a difundiram no Brasil, constatando a veracidade da expressão "a cada canto, o seu Espírito Santo", na referência não tanto à questão numérica, como às peculiaridades adquiridas pelos festejos após o com- 
tato com os costumes locais. No entanto, as principais tradições ritualísticas continuam sendo surpreendentemente preservadas e difundidas.

$\mathrm{Na}$ descrição analítica da Festa do Divino Espírito Santo em Viana apareceram vários fatores que viabilizavam a manutenção da Festa por mais de dois séculos, entre eles a força da tradição familiar, a grande motivação pessoal em participar da Festa, o conhecimento dos rituais e da sua simbologia, o papel da religião e da Igreja Católica na condução dos festejos.

No decorrer desta pesquisa, confirmamos que a açorianidade se encontra presente nos rituais e na simbologia da Festa do Divino em Viana, mesmo que os atuais organizadores da Festa não sejam descendentes de açorianos, não tenham conhecimento das origens da celebração ou não verbalizem esse fato em suas narrativas - a manutenção da Festa do Divino, por si só, atesta uma forte herança cultural açoriana na memória coletiva dos habitantes do município. Todavia, entre as narrativas, foi recorrente a fala de pesar com relação à escassa participação dos mais jovens nos rituais religiosos dos festejos. De certa forma, os entrevistados deixaram transparecer a preocupação de que a tradição não seja levada adiante para as futuras gerações.

Nas narrativas, também foi possível confirmar a ocorrência de diversas mudanças incorporadas ou subtraídas ao antigo padrão de celebração da Festa em Viana. Nos depoimentos prestados, principalmente pelos idosos, há um tom de saudosismo quando esses se referem à Festa de "antigamente", ou seja, à Festa que ficou guardada em suas memórias. Entre as mudanças mais citadas na estrutura ritual da Festa, estão: a diminuição do público participante, principalmente durante as procissões e as missas; o comportamento inadequado dos participantes, a cobrança pelos alimentos e, por fim, a preocupação excessiva com o lucro ao invés da religiosidade.

As adaptações e/ou ressignificações ocorridas em Viana também ocorreram em Festas do Divino realizadas noutros lugares do Brasil. Em nosso entendimento, elas refletem um processo sociocultural muito mais amplo, que envolve um conjunto de mudanças ocorridas na localidade, no estado e no país, provocando "abrasileiramentos".

Portanto, a Festa do Divino Espírito Santo continua sendo ressignificada até hoje, mas respeitando uma estrutura ritual que remete às origens açorianas, apesar de coexistir com influências da cultural local em seu conjunto cerimonial. Como explica Halbwachs (2013), a memória coletiva possui uma íntima ligação com a tradição, refletindo as representações de um determinado grupo social. Ao mesmo tempo em que se relaciona com a tradição, ela também a dinamiza, representando os fatos e estabelecendo uma continuidade entre o passado e o presente. 
Sendo assim, compreendemos que a Festa do Divino em Viana, apresenta-se como um indicador empírico da memória coletiva da comunidade analisada, a partir da contribuição das memórias e ações dos indivíduos envolvidos em sua transmissão e manutenção.

\section{REFERÊNCIAS}

Angelo, E. (2011). Trajetórias dos imigrantes açorianos em São Paulo: Processos de formação, transformação e ressignificação das representações culturais (Tese de doutorado, Pontifícia Universidade Católica de São Paulo). Sistema de Publicação Eletrônica de Teses e Dissertações (TEDE) PUC-SP. https://tede2.pucsp.br/bitstream/handle/12671/1/Elis\%20Regina\%20Barbosa\%20Angelo.pdf

Balestrero, H. (2012). Subsídios para o estudo da geografia e da história do município de Viana. JEP Gráfica.

Brandão, C. (1985). Memórias do sagrado: estudos de religião e ritual. Paulinas.

Cruz, J. (2014). A festa do Divino Espírito Santo em Gravataí/RS ao longo dos séculos XX - XXI (Dissertação de mestrado, Universidade do Vale do Rio dos Sinos). Repositório Digital da Biblioteca da Unisinos (RDBU). http://www.repositorio.jesuita.org.br/bitstream/handle/UNISINOS/5165/Jairton\%200rtiz\%20da\%20Cruz_.pdf

Durkheim, E. (1989). As formas elementares da vida religiosa. Paulinas.

Guarinello, N. (2001). Festa, trabalho e cotidiano. Em I. Jancsó \& I. Kantor (eds.), Festa: cultura e sociabilidade na América portuguesa (v. 2, pp. 969-975). Imprensa Oficial; HUCITEC; EDUSP; FAPESP.

Halbwachs, M. (2013). A memória coletiva. Centauro.

Hobsbawn, E. (2014). Invenção das tradições. Paz e Terra.

Leal, J. (1994). As Festas do Espírito Santo nos Açores: um estudo de Antropologia Social. Publicações Dom Quixote. https://doi.org/10.4000/books.etnograficapress.1989

Leal, J. (2017). O culto do divino: migrações e transformações. Edições 70.

Mariano, F. (2012). Patrimônio e Memória: o Divino em Viana do Espírito Santo (Dissertação de mestrado, Universidade Federal do Espírito Santo). Repositório Institucional da Universidade Federal do Espírito Santo (RiUfes). http://repositorio.ufes.br/bitstream/10/2091/1/tese_5962_Disserta\%C3\%A7\%C3\%A3o\%20Fabiene.pdf

Medina, J. (2007). O Ciclo do Espírito Santo / The Holy Ghost Cycle. Nova Gráfica.

Moraes, F. (2003). A Festa do Divino em Mogi das Cruzes: folclore e massificação na sociedade contemporânea. Annablume; FAPESP.

Neves, G. (2008). Coletânea de estudos e registros do folclore capixaba: 1944-1982. Centro Cultural de Estudos e Pesquisas do Espírito Santo.

Pollak, M. (1989). Memória, esquecimento, silêncio. Revista Estudos Históricos CPDOC-FGV, 2(3), 3-15.

Rocha, L. (2008). Viagem de Pedro II ao Espírito Santo. Coleção Canaã.

Saint-Hilaire. A. (1974). Viagem ao Espírito Santo e Rio Doce. Itatiaia.

Zaluar, A. (1983). Os homens de Deus: um estudo dos santos e das festas no catolicismo popular. Zahar Editores. 